\title{
Protein S deficiency in HIV associated ischaemic stroke: an epiphenomenon of HIV infection
}

\section{A Mochan, M Modi, G Modi}

The purpose of the study was to determine the relevance of protein $\mathrm{S}$ deficiency in HIV infected patients with ischaemic stroke. In total, 33 HIV positive patients with ischaemic stroke, previously described by us, were prospectively compared with control groups for occurrence of protein $\mathrm{S}$ deficiency. The control groups comprised an equal number of consecutive matched HIV positive and negative patients without and with stroke respectively. Data were analysed in contingency tables using Fisher's exact test. Protein S deficiency occurred significantly more frequently in HIV positive compared with HIV negative stroke patients $(p<0.001)$. However, by including HIV positive patients without stroke as a control group and comparing this group with the HIV positive stroke group we found that protein $\mathrm{S}$ deficiency is statistically related to HIV infection and not stroke occurrence. Our data indicate that the presence of protein S deficiency in HIV positive patients with stroke is an epiphenomenon of HIV infection.

$\mathrm{S}$ troke in patients with HIV infection has been ascribed to vascular abnormalities, coagulation disorders (in particular, protein $S$ deficiency) and cardioembolic disease in several clinical and pathological studies. ${ }^{1-5}$

Protein $S$ deficiency in HIV infection is thought to result from autoantibodies and the release of tumour necrosis factor alpha..$^{6-9}$ The relationship between protein $\mathrm{S}$ deficiency and the occurrence of stroke is unclear. A retrospective case control study demonstrated a significant correlation between protein $\mathrm{S}$ deficiency and the occurrence of stroke in HIV positive compared with HIV negative patients. ${ }^{2}$ In a prospective case series that we undertook, 17 of 33 HIV positive patients with cerebral infarctions had a coagulopathy, and 11 of these patients had protein S deficiency. ${ }^{3}$ We did not have HIV negative stroke controls in that study.

We therefore undertook a prospective study of protein $S$ deficiency in comparative control groups to our HIV positive stroke cohort described previously. ${ }^{3}$

\section{PATIENTS AND METHODS}

The study design was a case control study to determine the relevance of protein S deficiency in HIV associated stroke. Approval for the study was obtained from the institutional ethics review board.

We had previously studied and reported 35 adult (age $>18$ years) HIV infected patients presenting with stroke, of whom 33 patients had cerebral infarctions and 11 of these patients had protein S deficiency $(33 \%)$. $^{3}$

This study was prospectively expanded to include two control groups: (a) 33 consecutively identified HIV negative patients with cerebral infarction matched for age and sex, and $(b) 33$ consecutively identified HIV positive patients without cerebral infarction, matched for age, sex, and CD4 count. Thus, the total number of patients was 99, with 33 in each group. Mean age was 32.1 years (range 20-61 years), and female to male ratio was 1.5:1. The patients were inpatients of the medical wards at the Chris Hani Baragwanath Hospital (CHBH), Soweto, South Africa.

In the stroke patients, the presence of cerebral infarction had to be confirmed on computed tomography (CT) scan. Protein $\mathrm{S}$ activity in both control groups was determined using the same functional assay measuring free protein $S$ activity as in the previously described cohort of HIV positive stroke patients. The method used was as described by the manufacturer (Ilex Automated Coagulation Analyzer; Ilex Medical Ltd, Israel). The assay was repeated in the stroke patients at 3 months. Abnormalities that persisted were then interpreted as relevant. ${ }^{10}$ The control group of HIV negative stroke patients had protein $S$ assays as part of standard investigations. The control group of HIV positive patients without stroke had protein S assays as part of the study protocol but not for any clinical indication.

\section{RESULTS}

Group 1: HIV positive patients with stroke (previously reported) ${ }^{3}$

Eight patients (24\%) had meningitis (3 tuberculous, I pyogenic and 4 viral), 3 (9\%) had a potential cardioembolic source (HIV related dilated cardiomyopathy, postpartum cardiomyopathy and mitral valve prolapse respectively), 2 had hypertension (6\%), and 17 (51\%) had a coagulopathy. Of these 17 patients, protein $S$ deficiency occurred in 11 , protein C deficiency in 1 , and antiphospholipid antibodies were found in 5 . The protein $S$ deficiency was found at both measurements - that is, on admission and at repeat testing 3 months later, in all 11 patients. A vasculopathy/vasculitis occurred in four patients (12\%). In these 17 patients, more than one underlying cause was found in 10 patients, one cause was identified in 2 patients, while no potential cause was identified in 5 patients $(15 \%)$.

\section{Group 2: HIV negative patients with stroke}

Four patients had a potential cardioembolic source (12\%), 4 had hypertension (12\%), 4 had carotid artery dissection ( $12 \%), 3$ had vasculitis (9\%), 3 had meningitis (9\%), 2 had eclampsia (7\%), I had fibromuscular dysplasia (3\%), and 12 had no identified cause (36\%).

\section{Group 3: HIV positive patients without stroke}

Fifteen patients had pulmonary tuberculosis $(45 \%), 8$ had bronchopneumonia (24\%), 7 had community acquired lobar pneumonia (21\%), 2 had Guillain-Barré syndrome (7\%), and 1 had bilateral Bell's palsy (3\%).

\section{CD4 counts}

The CD4 counts of the groups 1 and 3 were measured at the time of admission: eight patients $(23 \%)$ were CDC category 1 , $13(37 \%)$ were category 2 , and $14(40 \%)$ were category 3 in each group. ${ }^{11}$ 


\section{Protein S deficiency}

Protein S deficiency was found in 11 of 33 patients in group 1 (HIV positive patients with stroke), none of the 33 patients in group 2 (HIV negative patients with stroke) and in 12 of 33 in group 3 (HIV positive patients without stroke).

Analysis of the protein $\mathrm{S}$ data in relation to stroke in HIV positive and negative patients, and in relation to HIV infection in the absence of stroke was performed using a contingency table. By Fisher's exact test, groups 1 and 3 did not differ, but both were significantly different from group 2 $(\mathrm{p}<0.001)$. The data show a significant association between HIV infection and protein $S$ deficiency, but not between stroke and protein $\mathrm{S}$ deficiency.

\section{DISCUSSION}

The data we have obtained here concur with the literature that HIV infection is significantly $(\mathrm{p}<0.001)$ associated with protein $\mathrm{S}$ deficiency. ${ }^{12-17}$ With respect to HIV infection and ischaemic stroke, the retrospective case control study from the USA showed that the association is statistically significant. ${ }^{2}$ Similarly, we also found that protein S deficiency occurred significantly more frequently in HIV positive than in HIV negative stroke patients $(\mathrm{p}<0.001)$.

Furthermore, by including HIV positive patients without stroke as a control group and comparing this group with the HIV positive stroke group we found that protein $S$ deficiency is statistically related to the HIV infection rather than the stroke occurrence $(\mathrm{p}<0.001)$. Of the 33 HIV positive stroke patients, 11 had protein S deficiency, and 12 of the 33 HIV positive control patients without stoke had protein $S$ deficiency.

The role of hereditary or acquired protein S deficiency in the aetiopathogenesis of stroke remains poorly understood. ${ }^{18}$ Familial protein $\mathrm{S}$ deficiency has been linked to a hypercoagulable state that may present clinically with recurrent venous thrombosis but rarely with arterial cerebral infarction. ${ }^{18}$ With acquired protein $S$ deficiency there is no consensus on its relationship to ischaemic stroke. ${ }^{18-21}$ In terms of HIV infection our data support the concept that its occurrence is an epiphenomenon of the HIV infection itself.

The limitations of our study include the relatively small numbers of patients and the comparison of prospectively defined control groups with a previously reported cohort; however, this may be justified by the fact that the patients are all from the same region and hospital and that the control groups were appropriately matched.

\section{CONCLUSION}

Protein S deficiency in HIV positive patients with stroke is an epiphenomenon of the HIV infection.

\section{Authors' affiliations}

A Mochan, G Modi, Division of Neurology, Department of Neurosciences, Department of Radiation Sciences in the School of Clinical Medicine, Faculty of Health Sciences, University of the Witwatersrand, Johannesburg, South Africa
M Modi, Division of Neurology, Department of Neurosciences, School of Clinical Medicine, Faculty of Health Sciences, University of the

Witwatersrand, Johannesburg, South Africa

Competing interests: there are no competing interests

Correspondence to: Professor G Modi, PO Box 909, Lenasia 1820, South Africa; gmodicns@mweb.co.za

Received 29 November 2004

In revised form 11 May 2005

Accepted 13 May 2005

\section{REFERENCES}

1 Pinto AN. AIDS and cerebrovascular disease. Stroke 1996;27:538-43.

2 Qureshi Al, Janssen RS, Karon JM, et al. Human immunodeficiency virus infection and stroke in young patients. Arch Neurol 1997;54:1150-3.

3 Mochan A, Modi M, Modi G. Stroke in black South African HIV-positive patients: A prospective analysis. Stroke 2003;34:10-15.

4 Hoffmann M, Berger JR, Nath A, et al. Cerebrovascular disease in young, HIV-infected, black Africans in the KwaZulu Natal Province of South Africa J Neurovirol 2000;6:229-36.

5 Connor MD, Lammie GA, Bell JE, et al. Cerebral infarction in adult AIDS patients: Observations from the Edinburgh Autopsy Cohort. Stroke 2000;31:2117-26.

6 Lafeuillade A, Sorice M, Griggi T, et al. Role of autoimmunity in protein S deficiency during HIV-1 infection. Infection 1994;22:201-3.

7 Abuaf N, Laperche S, Rajoely B, et al. Autoantibodies to phospholipid and to the coagulation proteins in AIDS. Thromb Haemost 1997;77:856-61

8 Hooper WC, Phillips DJ, Ribeiro MJ, et al. Tumor necrosis factor-alpha downregulates protein $\mathrm{S}$ secretion in human microvascular and umbilical vein endothelial cells but not in the HepG-2 hepatoma cell line. Blood 1994;84:483-9.

9 Sorice M, Arcieri P, Griggi T, et al. Inhibition of protein S by autoantibodies in patients with acquired protein $S$ deficiency. Thromb Haemost 1996;75:555-9.

10 Bushnell CD, Goldstein LB. Diagnostic testing for coagulopathies in patients with ischemic stroke. Stroke 2000;31:3067-78.

11 Centers for Disease Control. 1993 revised classifications system for HIV infection and expanded surveillance case definition for AIDS among adolescents and adults. MMWR Morbid Mortal Wkly Rep 1993:1-19.

12 Stahl CP, Wideman CS, Spira TJ, et al. Protein S deficiency in men with longterm human immunodeficiency virus infection. Blood 1993;81:1801-7.

13 Bissuel F, Berruyer M, Causse X, et al. Acquired protein S deficiency: correlation with advanced disease in HIV-1-infected patients. J Acquir Immune Defic Syndr 1992;5:484-9.

14 Sorice M, Griggi T, Arcieri P, et al. Protein S and HIV infection. The role of anticardiolipin and anti-protein $\mathrm{S}$ antibodies. Thromb Res 1994;73:165-75.

15 Sugerman RW, Church JA, Goldsmith JC, et al. Acquired protein S deficiency in children infected with human immunodeficiency virus. Pediatr Infect Dis J 1996;15:106-11.

16 Hassell KL, Kressin DC, Neumann A, et al. Correlation of antiphospholipid antibodies and protein $\mathrm{S}$ deficiency with thrombosis in HIV-infected men. Blood Coagul Fibrinolysis 1994;5:455-62.

17 Erbe M, Rickerts V, Bauersachs RM, et al. Acquired protein $C$ and protein S deficiency in HIV-infected patients. Clin Appl Thromb Hemost 2003;9:325-31.

18 Coull BM, Goodnight SH. Antiphospholipid antibodies and coagulation disorders in ischaemic stroke. In: Barnett HJM, Mohr JP, Stein BM, Yatsu FM, eds. Stroke: pathophysiology, diagnosis, and management, 2nd ed. New York: Churchill Livingstone, 1992:859-61.

19 Barinagarrementeria F, Cantu-Brito C, De La Pena A, et al. Prothrombotic states in young people with idiopathic stroke. A prospective study. Stroke 1994;25:287-90.

20 Munts AG, van Genderen PJJ, Dippel DWJ, et al. Coagulation disorders in young adults with acute cerebral ischaemia. J Neurol 1998;245:21-5.

21 Mayer SA, Sacco RL, Hurlet-Jensen A, et al. Free protein S deficiency in acute ischaemic stroke. A case control study. Stroke 1993;24:224-7. 